\title{
Pengembangan Merek melalui Personalisasi, Kustomisasi dan Komunikasi Kreatif
}

\author{
Suharyanti, Ajeng Harista, Dessy Kania dan Mirana Hanathasia \\ Program Studi Ilmu Komunikasi Universitas Bakrie, Jakarta \\ Email: suharyan3in1@gmail.com
}

\begin{abstract}
In today's hypercompetitive era, a small and medium enterprise (SME) should increase the added values of its business through appropriate branding strategy. During this time, branding is synonymous with the companies and big brands. In fact, branding should start from the early stages of a business so that the brand has a strong foundation. Brand development-based entrepreneurship strategy is called Branderpreneurship. Using case study method through the lens of circle of values development model in the Wijaya's theory of Branderpreneurship, the authors analyzed an SME brand that provides creative medium services for young people in creating expressive fashion branded Duo Langit. Data collected by observation, document searches and in-depth interviews with the owner of Duo Langit and triangulate it with consumers. The results showed that Duo Langit is very prominent in identifying values, creating values and communicating values by personalizing and customizing the products as well as an intuitive understanding of the young people insights, while lack in maintaining and evaluating values due to less sharply in warying the competitors.
\end{abstract}

Keywords: Branderpreneurship, SME, Duo Langit, Personalization, Customization

\begin{abstract}
Abstrak
Di era hiperkompetitif dewasa ini, sebuah usaha kecil dan menengah (UKM) harus meningkatkan nilai tambah usahanya melalui strategi pemerekan (branding) yang tepat. Selama ini branding identik dengan perusahaan-perusahaan dan merek-merek besar. Padahal, branding justru harus dimulai dari tahap awal sebuah usaha agar memiliki pondasi yang kuat. Strategi kewirausahaan berbasis pengembangan merek ini disebut Branderpreneurship. Dengan menggunakan metode studi kasus melalui lensa model circle of values development yang merupakan inti teori Wijaya tentang Branderpreneurship, penulis menganalisis sebuah merek UKM jasa medium kreasi fesyen ekspresif anak muda bermerek Duo Langit. Pengumpulan data dilakukan dengan observasi, penelusuran dokumen dan wawancara mendalam terhadap pemilik Duo Langit dan mentriangulasikannya dengan konsumen Duo Langit. Hasil penelitian menunjukkan bahwa Duo Langit sangat menonjol dalam identifying values, creating values dan communicating values dengan personalisasi dan kustomisasi produk serta pemahaman yang intuitif terhadap insights anak muda, sementara lemah dalam maintaining values dan evaluating values karena kurang tajam dalam mewaspadai kompetitor.
\end{abstract}

Kata kunci: Branderpreneurship, UKM, Duo Langit, Personalisasi, Kustomisasi 


\section{Pendahuluan}

Indonesia merupakan negara yang memiliki sumber daya alam dan sumber daya manusia yang sangat kaya. Hal ini menjadi potensi besar yang mendorong masyarakat untuk meningkatkan ekonomi Indonesia melalui Usaha Kecil dan Menengah atau yang biasa disebut sebagai UKM. Di negara lain, UKM memiliki peran yang signifikan dalam perkembangan ekonomi baik secara mikro maupun makro seperti di Jepang, Amerika Serikat, Jerman, dan Italia. Pemerintahan di negara-negara tersebut sangat mendukung kebijakan mengenai UKM karena UKM juga dianggap sebagai penopang ekonomi di saat terjadi krisis global.

UKM di Indonesia sendiri setiap tahun mengalami pertumbuhan yang sangat pesat dengan penyerapan tenaga kerja yang besar, yang mayoritas anak muda dan wanita. Mengutip dari laman www.depkop.go.id, peran penting UKM dalam perekonomian suatu negara diindikasikan oleh tiga hal, pertama, jumlah usaha yang banyak dan terdapat di setiap sektor atau bidang usaha. Kedua, mempunyai potensi besar dalam penyerapan tenaga kerja. Ketiga, memberi kontribusi yang signifikan terhadap pendapatan negara (Rachman, 2016). Data BPS (www.bps.go.id) 2007 menunjukkan jumlah UKM mencapai 99,99\% dari total unit usaha di Indonesia, sementara hingga 2013, sektor UKM di Indonesia mampu menyerap 99,8\% dari total angkatan kerja.

Dari setiap rupiah investasi di UKM secara signifikan menciptakan lebih banyak lapangan kerja dibandingkan investasi yang sama di usaha besar, sementara di sisi lain, UKM juga menyumbang 56\% dari total Produk Domestik Bruto (PDB) Indonesia di tahun 2013. Sumbangan UKM di Indonesia terhadap kemajuan pertumbuhan ekonomi nasional terutama didorong oleh kegiatan ekspornya yang terus meningkat.

Dengan perkembangan UKM yang sangat pesat di setiap tahunnya, menunjukkan bahwa dunia kewirausahaan di Indonesia sedang bergairah. Banyak entrepreneur atau wirausahawan yang bersaing satu sama lain untuk mengembangkan usaha mereka, sehingga dibutuhkan strategi khusus agar tidak terdepak dari arena pertarungan. Salah satu strategi penting yang memberi kontribusi signifikan bagi energi persaingan tersebut adalah dengan menaruh perhatian serius pada pengembangan nilai merek dalam usaha mereka.

Wirausahawan perlu memperhatikan keberlangsungan usahanya dari semua aspek baik itu manajemen, pemasaran dan produk. Jika berkaitan dengan produk maka perlu strategi menyusun branding atau pemerekan Usaha Kecil Menengah (UKM) untuk produk-produk dan layanan yang ditawarkan. Wirausahawan harus mengetahui setiap detil produk mulai dari kemasan hingga standar kualitas produk itu sendiri. Pemerekan UKM akan menaikkan kepercayaan masyarakat terhadap produk UKM, memberi makna bagi kehidupan konsumen, karena merek atau brand adalah tanda jejak yang tertinggal di benak dan hati konsumen yang menimbulkan makna dan perasaan tertentu (Wijaya, 2013: 55).

Menurut Sadat (2009: 19), merek tidak dapat dipisahkan dari eksistensi sebuah produk. Akan tetapi, hal ini masih kurang disadari oleh sebagian besar pemasar. Merek sebagai pembentuk karakter produk lebih berfungsi saat ditawarkan kepada konsumen dalam lingkungan persaingan yang ketat. Banyaknya jumlah produk sejenis membuat konsumen kesulitan dalam melakukan identifikasi secara tepat dan akurat terhadap atribut dan manfaat yang ditawarkan (Keller, 2013). Di sinilah peran strategis merek sebagai guide bagi konsumen terkait kualitas, daya tahan, nilai, citra atau gaya yang tidak dimiliki merek lainnya. Wijaya (2012) menyebut fenomena ini sebagai shifted paradigm dalam komunikasi pemasaran di mana awalnya fokus pada penjualan menjadi fokus pada pemerekan (branding) melalui komunikasi yang membentuk persepsi.

Ada sebagian dari penggerak UKM di Indonesia yang sudah menerapkan strategi pengembangan merek dalam usaha mereka. 
Namun demikian, tidak bisa dipungkiri juga masih ada beberapa penggerak UKM yang masih kurang, bahkan tidak menerapkan strategi pengembangan merek dalam usaha mereka. Karena itu pelaku UKM perlu mengenal dan memiliki sikap Branderpreneurship. Menurut Wijaya (2011), Branderpreneurship adalah suatu penerapan strategi pengembangan merek yang terarah dan terpadu dengan memaksimalkan sumber-sumber daya yang ada dalam menunjang pengembangan usaha sehingga memberikan nilai tambah bagi kewirausahaan.

Branderpreneurship juga dapat dipahami sebagai sikap mental atau mindset yang menyinergikan semangat kewirausahaan dan strategi pengembangan merek (Wijaya, 2011). Beberapa kajian mengenai strategi pengembangan nilai merek UKM di antaranya UKM keripik singkong Maicih dan salon Waxing Corner (Wijaya \& Hanathasia, 2012; Wijaya \& Sutawidjaya, 2015; Wijaya, et al., 2016).

Dalam mengembangkan nilai merek, Maicih berawal dari ide menciptakan keripik singkong yang beda dari keripik singkong pada umumnya. Perbedaan Maicih dengan keripik lainnya terletak pada rasa keripik yang kaya akan rempah-rempah Indonesia. Keripik singkong Maicih memiliki tingkat kepedasan produk dan cara mengomunikasikan merek. Maicih fokus pada pengembangan nilai merek secara terarah, sehingga inovasi bukan sematamata pada produk, melainkan lebih kepada cara komunikasi dan pemasarannya (Wijaya \& Sutawidjaya, 2015; Wijaya, et al, 2016).

Maicih melakukan terobosan pada cara komunikasi dan pemasaran produk dengan menggunakan social media dan menciptakan nilai merek berdasarkan insight konsumen anak muda yang senang tantangan. Maicih terbukti sukses mengidentifikasi nilai apa yang dapat ditawarkan kepada konsumennya, agar mereka tidak sekadar mengonsumsi keripik. Termasuk, mengidentifikasi sasaran konsumennya dengan tepat, yakni anak muda, yang kebanyakan memang doyan jajan, ngemil, suka tantangan dan punya rasa keingintahuan atau penasaran yang sangat tinggi. Karena itu, agar tidak sekadar menjadi barang cemilan, keripik singkong Maicih dibubuhi spirit tantangan melalui level kepedasannya.

Maicih juga sukses menciptakan dan melakukan delivering atau pendistribusian nilai mereknya melalui sistem penjualan mobile dan berjejaring yang sangat kreatif dengan penamaan-penamaan yang unik, sesuai dengan target konsumen. Penjualan melalui social media juga merupakan cara yang cerdas seperti melalui twitter, karena selain nyaris tanpa biaya, juga sangat fokus sebagai medium favorit anak muda saat ini. Maicih juga berinovasi dengan menciptakan varian baru seperti keripik bakso goreng (basreng), seblak original, seblak keju, dan lainnya, yang kemudian merambah ke pasar global melalui merek Spicy Granny (Wijaya \& Sutawidjaya, 2015).

Penelitian kedua adalah UKM Waxing Corner yakni UKM yang menawarkan jasa perawatan kecantikan berupa waxing atau pencabutan bulu menggunakan cara moderen. Maksud dari kata "moderen" di sini adalah proses pencabutan bulu yang menggunakan wax atau lilin yang dicampur dengan bahan-bahan alami seperti ekstrak melon, biji matahari dan pisang. Waxing Corner tidak hanya menawarkan layanan berupa waxing, tetapi juga memperhatikan dan bertanggungjawab bagaimana kelanjutan dari kulit yang telah di-waxing tersebut (Wijaya \& Hanathasia, 2012).

Namun, nilai yang disampaikan oleh Waxing Corner hanya sebatas fungsional dari bahan baku yang digunakan untuk waxing, belum menyentuh sisi emosional, simbolik, apalagi sosial. Dalam mengkomunikasikan nilainya, Waxing Corner menggunakan media sosial, blog, brosur, situs belanja daring Deal Keren, serta memberikan diskon melalui member card kepada para pelanggan yang merupakan strategi untuk mempertahankan loyalitas pelanggan. Guna menambah nilai mereknya, Waxing Corner pun berencana membuka waxing khusus pria. Di sini, baik Maicih maupun Waxing Corner telah berusaha mengembangkan nilai mereknya 
(meskipun ada yang belum maksimal) yang dari perspektif branderpreneurship disebut sebagai kewirausahaan berbasis pengembangan (dan komunikasi) nilai merek (Wijaya, et al, 2016).

Tak dapat dipungkiri bahwa dalam dunia pemasaran, banyak pemasar yang menggunakan berbagai strategi pemasaran dalam memasarkan produknya. Menurut Assauri (2010: 168), strategi pemasaran adalah serangkaian tujuan dan sasaran, kebijakan dan aturan yang memberi arah kepada usaha-usaha pemasaran perusahaan dari waktu ke waktu, pada masingmasing tingkatan dan acuan serta alokasinya, terutama sebagai tanggapan perusahaan dalam menghadapi lingkungan dan keadaan persaingan yang selalu berubah. Karena itu, penentuan strategi pemasaran harus didasarkan atas analisis lingkungan dan internal perusahaan melalui analisis keunggulan dan kelemahan perusahaan, serta analisis kesempatan dan ancaman yang dihadapi perusahaan dari lingkungannya (Suharyanti, 2011). Salah satu dari sekian banyak strategi pemasaran yang digunakan oleh pemasar adalah strategi sasaran pasar dan marketing mix.

Assauri (2010: 175) menjelaskan bahwa penetapan strategi sasaran pasar merupakan hasil perkembangan terakhir dari pendekatan atau pandangan pimpinan perusahaan dalam memasarkan produknya, di mana perusahaan dapat mengembangkan produk yang tepat untuk masing-masing pasar sebagai sasaran pasar, dan hanya berfokus pada sasaran pasar produk yang perusahaan ciptakan. Adapun marketing mix merupakan kombinasi variabel atau kegiatan yang merupakan inti dari sistem pemasaran, variabel yang dapat dikendalikan oleh perusahaan untuk mempengaruhi reaksi konsumen. Variabel marketing mix adalah strategi produk, harga, distribusi, dam promosi.

Dari berbagai contoh strategi pemasaran yang sudah ada, strategi pemasaran yang spesifik mengaitkan komunikasi merek dan pola pikir kewirausahaan dalam pengembangan usaha belum terlalu banyak diulas. Karena itu, pendekatan yang digunakan dalam penelitian ini adalah studi kasus dari kacamata konsep branderpreneurship yakni dengan menganalisis data dan informasi melalui lensa model the circle of values development yang merupakan inti dari branderpreneurship. Strategi branderpreneurship memiliki berbagai dimensi dalam pengembangan nilai merek, yakni identifying values (mengidentifikasi nilai), creating values (menciptakan nilai), delivering/ distributing values (mengantarkan/ mendistribusikan nilai), communicating values (mengomunikasikan nilai), maintaining values (merawat/ menjaga nilai), evaluating values (mengevaluasi nilai), dan updating values (memperbarui nilai) (Wijaya, 2011). Dengan demikian, pendekatan branderpreneurship sangat tepat digunakan untuk menganalisis pengembangan nilai suatu merek UKM yang memiliki semangat kewirausahaan, dikarenakan elemen-elemen yang dimiliki oleh branderpreneurship merupakan elemenelemen yang terhubung satu sama lain dan sudah mewakili strategi pemerekan yang lengkap untuk menganalisis pengembangan nilai merek yang bersinergi dengan semangat kewirausahaan (Wijaya \& Hanathasia, 2012; Wijaya et al., 2016).

Sementara itu, Duo Langit sebagai obyek studi ini merupakan merek UKM yang bergerak di bidang jasa printing atau sablon $t$-shirt dengan sistem direct to garment (DTG). DTG merupakan suatu proses printing/ sablon obyek atau image ke media kain (t-shirt), menggunakan printer yang dirancang khusus dengan menggunakan tinta khusus textile sehingga hasil printing tidak luntur ketika $t$-shirt dicuci, dan gambar yang tercetak tidak timbul ke permukaan baju. Ide yang ditawarkan oleh Duo Langit ke konsumen adalah jasa cetakan $t$-shirt di mana Duo Langit tidak menjual desain atau motif t-shirt melainkan ide dalam membuat desain t-shirt berasal dari konsumen.

Konsumen memiliki hak untuk menentukan ide atau desain yang mereka miliki untuk dituangkan ke media kain (t-shirt). Dengan demikian, nilai yang ditawarkan oleh Duo Langit adalah mengajak konsumen 
untuk bercerita dan berkreasi melalui $t$-shirt. Konsumen dapat membuat $t$-shirt yang sesuai dengan keinginan mereka dan kesukaan mereka. T-shirt tersebut dapat menjadi media konsumen untuk menunjukkan, mengenalkan atau mengomunikasi pesan-pesan yang mewakili kepribadian konsumen yang ditujukan kepada orang lain. Dari paparan ini, peneliti kemudian berusaha meneliti lebih lanjut mengenai strategi pengembangan nilai merek UKM "Duo Langit" ditinjau dari pendekatan branderpreneurship.

Sebagaimana dijelaskan sebelumnya, Branderpreneurship adalah suatu penerapan strategi pengembangan merek yang terarah dan terpadu dengan memaksimalkan sumber-sumber daya yang ada dalam menunjang pengembangan usaha sehingga memberikan nilai tambah bagi kewirausahaan (Wijaya, 2011). Terdapat langkah-langkah strategis dalam pengembangan dan pengelolaan nilai (values development) yang merupakan inti branderpreneurship, sehingga merek yang dikelola dapat menunjang pengembangan suatu usaha. Yang pertama adalah Identifying Values. Sebelum memulai usaha atau menelurkan sebuah produk/ servis, seorang wirausahawan sebaiknya menggali informasi dari konsumen atau pasar mengenai apa yang sesungguhnya diinginkan, dibutuhkan, didambakan, diobsesikan, baik secara sadar maupun tanpa sadar oleh konsumen berkaitan dengan ide usaha/ produk/ servis yang akan diluncurkan. Proses ini disebut consumer insights. Pemahaman yang baik dan mendalam terhadap konsumen akan meminimalisir the failure of product launching, sekaligus berpotensi menimbulkan emotional bond secara efektif, karena konsumen merasakan apa yang ditawarkan seolah mengerti dirinya yang sesungguhnya.

Kedua, Creating Values. Berdasarkan consumer insights yang baik, seorang wirausahawan kemudian mulai mengembangkan bisnis/ produk/ servisnya dengan melakukan modifikasi dari ide awal. Hal ini dapat berupa penambahan atau penggantian fitur dan atribut produk, modifikasi lokasi, waktu, kemasan atau the way of consuming maupun the way of getting involved. Pendek kata, value yang diciptakan berdasarkan consumer insights dapat berkaitan dengan konten maupun konteks produk. Dalam tahap ini juga seorang wirausahawan mendialogkan hasil temuan dengan situasi kompetisi, sehingga apa yang diputuskan untuk ditawarkan kepada konsumen tidak hanya sesuai dengan insights konsumen, tetapi juga memiliki diferensiasi yang tajam serta keunggulan yang kompetitif (competitive advantage).

Ketiga, Delivering values. Setelah modifikasi ide dan kreasi penawaran dari usaha/ produk/ servis telah final, maka seorang wirausahawan kemudian mengemas dan menyampaikannya kepada konsumen melalui berbagai saluran distribusi yang sesuai dengan insights konsumen. Di sini fungsi distribusi dan saluran penjualan/ pengantaran nilai merek memegang peran utama. Dengan memahami kebiasaan konsumen dan tempat-tempat maupun cara penyampaian yang membuat nyaman konsumen (baik online maupun offline, tangible maupun intangible), seorang wirausahawan dapat menjalankan bisnisnya secara lebih efisien dan efektif, karena wirausahawan tidak perlu melakukan trial and error untuk mendapatkan dampak atau respons yang baik dari konsumen. Sekali lagi, peran consumer insights di tahap identifying values sangat penting dalam menunjang kesuksesan di setiap tahap pengembangan nilai.

Tahap keempat adalah Communicating Values. Jika penyampaian produk/ servis telah pasti dan lancar, yang tak kalah pentingnya adalah komunikasi. Nilai-nilai berupa penawaran dan benefit yang akan diperoleh konsumen dikomunikasikan secara tepat dan kreatif, sehingga merek lebih cepat dikenal (brand awareness), diketahui lebih banyak (brand knowledge), dipersepsikan bagus (brand image) dan dirasakan/ dialami secara baik (brand experience), sehingga membuat konsumen menjadi pelanggan yang setia (brand loyalty) dan bahkan membantu menjualkan nilai-nilai yang dirasakannya kepada konsumen lain dan 
masyarakat secara luas melalui berbagai medium (baik online berupa social media dan personal media maupun offline berupa traditional wordof-mouth serta media-media komunikasi lainnya) (Wijaya, 2013). Pemilihan media tentunya tak terlepas dari consumer insights. Jika konsumen pengguna atau calon pengguna produk kita lebih sering dan nyaman menggunakan social media, maka media tersebutlah yang sebaiknya menjadi media utama.

Jadi brand communication tidak harus menggunakan traditional mass media seperti televisi, koran, radio dan sebagainya. Sementara itu, alat komunikasi pemasaran dan merek yang dapat digunakan pun tidak harus berupa iklan konvensional di media massa yang cenderung berbiaya besar. Pemilik merek dapat menggunakan iklan-iklan di media alternatif dan kreatif seperti iklan ambient media, online direct mail, creative publicity, sponsorships, brand placement, guerilla advertising, dan banyak lagi. Menurut Wijaya, kuncinya adalah fokus, kreatif dan terpadu berdasarkan consumer insights yang baik.

Tahap kelima adalah Maintaining Values. Jika nilai-nilai yang ditawarkan merek telah dikomunikasikan dan berhasil menggaet sejumlah konsumen, maka tugas berikutnya bagi pemilik merek adalah menjaga konsumen agar tetap menikmati nilai-nilai yang telah ditawarkan oleh merek. Ini berarti, strategi yang harus dikembangkan adalah mengubah konsumen menjadi pelanggan (consumer to customer). Berbagai program dapat dibuat oleh pemilik merek/ usaha, dapat berupa retention program, loyalty program hingga brand community program.

Tahap keenam, Evaluating Values. Dalam periode tertentu, seorang wirausahawan harus melakukan evaluasi terhadap apa yang telah dilakukannya. Melihat sejauh mana tawaran-tawaran yang diberikan masih relevan, melihat perkembangan baru (teknologi, bencana, dan lain-lain) yang mengubah cara pandang konsumen dalam memaknai apa yang ditawarkan produk/ servis/ usaha, melihat bagaimana kiprah competitor, pengikut, merekmerek duplikat atau $\mathrm{KW}$, dan sebagainya. Lalu, bagaimana respon konsumen, respon masyarakat secara keseluruhan, respon media, respon mitra dan karyawan. Semua memerlukan evaluasi berupa audit merek dan riset konsumen. Menurut Wijaya, fungsi ini dapat diintegrasikan dengan fungsi consumer insights dan tidak harus berbiaya besar. Seorang wirausahawan dapat melakukannya sendiri atau memanfaatkan sumber daya yang ada.

Tahap terakhir dari values development adalah Updating values. Dari hasil evaluasi tersebut kemudian dilakukan pembaruan, pengkinian dan peningkatan nilai produk/ servis/ usaha sehingga konsumen senantiasamemperoleh sesuatu yang baru dan menyenangkan. Halhal baru dan menyenangkan dari apa yang ditawarkan kepada mereka pada akhirnya akan membuat hidup mereka pun lebih segar dan bernilai, sehingga menguatkan ikatan emosional dengan merek yang mereka gunakan. Updating values dapat berupa penambahan fitur dan benefit fungsional, emosional, simbolik dan sosial, atau dapat berupa pembaruan kemasan, layout ruangan, penambahan cabang, franchising, maupun cara komunikasi baru yang lebih kreatif sehingga memberi nilai tambah baru (new added values) bagi konsumen (Wijaya, 2011; Wijaya \& Hanathasia, 2012; Wijaya \& Sutawidjaya, 2015; Wijaya, et al, 2016).

Proses pengembangan nilai merek dalam teori Wijaya mengenai Branderpreneurship dapat dilihat pada gambar 1 .

Menurut Wijaya (2011), langkah-langkah dalam lingkaran pengembangan nilai-nilai tidak bersifat deterministik dan linier namun merupakan rangkaian yang saling berhubungan. Hal ini seperti beberapa jenis rangkaian yang menghubungkan setiap titik dari strategi pengembangan nilai. Karena itu, dalam kondisi tertentu, strategi untuk Creating Values mungkin dapat langsung menuju ke Communicating Values. Sementara itu, Delivering/ Distributing Values dapat dijalankan secara paralel dengan Maintaining Values, serta Communicating 
Gambar 1. Sirkuit pengembangan nilai yang merupakan inti Branderpreneurship

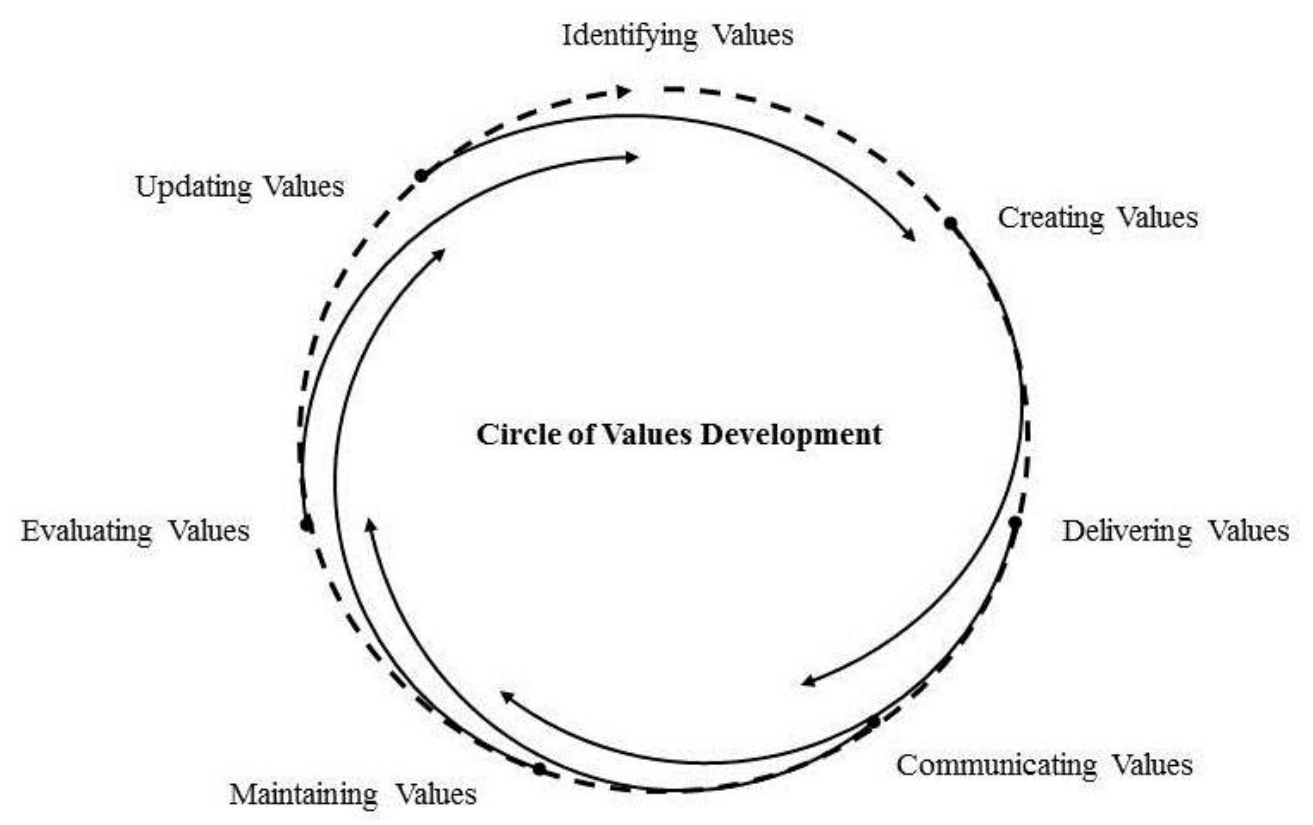

(sumber: Wijaya, 2011)

Values dapat berjalan beriringan dengan atau secara langsung ke Evaluating Values. Adapun Maintaining Values mungkin dapat bekerja pada saat yang sama dengan Updating Values, dan Evaluating Values dapat secara bersamaan melakukan peran Identifying Values yang bisa langsung pada Creating Values. Terakhir, tentu saja, Updating Values terkait erat dengan kegiatan Creating Values.

\section{Metode Penelitian}

Metode yang digunakan dalam penelitian ini adalah metode studi kasus mengenai Branderpreneurship. Studi Branderpreneurship merupakan pendekatan yang digunakan untuk menganalisis sebuah strategi pengembangan merek yang menyinergikan spirit kewirausahaan dan mindset pemerekan (Wijaya, 2011; Wijaya \& Hanathasia, 2012; Wijaya \& Sutawidjaya, 2015; Wijaya et al., 2016). Upaya yang bisa dilakukan untuk menganalisis sebuah merek usaha adalah menggunakan pendekatan branderpreneurship, yang dilakukan dengan cara menganalisis data dan informasi dari kacamata konsep the circle of values development yang merupakan inti dari branderpreneurship.
Menurut Wijaya (2011), elemen-elemen dalam branderpreneurship di antaranya adalah: 1) Identifying Values mencakup kegiatan dan proses consumer insights, market insights, dan brand insights, 2) Creating Values mencakup nilai-nilai merek dari segi functional, emotional, symbolic, social values, 3) Delivering Values mencakup pendistribuan dan penyampaian nilai kepada konsumen melalui channel atau saluran distribusi yang bersifat online maupun offline, 4) Communicating Values mencakup strategistrategi yang dilakukan mulai dari perancangan hingga eksekusi kreatif pesan (what-to-say), taktik atau tools strategi yang digunakan untuk menyampaikan pesan (how-to-say), media atau vehicle yang digunakan untuk menyampaikan pesan (where-to-say), dan strategi timing dan momen yang digunakan untuk menyampaikan pesan (when-to-say), 5) Maintaining Values mencakup program-program aktivitas yang dijalankan untuk membuat konsumen melakukan pembelian ulang (retention), untuk membuat konsumen loyal dan menjadi pelanggan tetap (loyalty), dan untuk membuat konsumen mencintai merek karena memiliki sense of belonging sehingga membentuk suatu 
komunitas penyuka merek (brand community), 6) Evaluating Values mencakup evaluasi diri (self-audit) dan evaluasi reaksi kompetitor terhadap nilai yang ditawarkan merek baik dari sisi nilai produk, konsumen maupun saluran dan strategi yang digunakan (competitive audit), juga evaluasi reaksi konsumen terhadap nilai merek (consumer audit), serta evaluasi perkembangan tren perilaku dan gaya hidup masyarakat secara umum terkait nilai merek yang ditawarkan (trend audit), dan 7) Updating Values mencakup langkah-langkah inovatif yang dilakukan untuk meningkatkan nilai merek, baik dari aspek produk (on product), aspek konsumen (on consumer), aspek distribusi (on channel), aspek strategi komunikasi (on communication) maupun dari aspek pengembangan usaha (on business).

Dalam penelitian ini, obyek yang diteliti adalah merek UKM Duo Langit, sebuah usaha kecil yang bergerak di bidang jasa kreatif bermedia kaos yang dapat dikatakan sebagai merek fesyen ekspresif. Berdirinya Duo Langit didasari oleh adanya kegemaran pemiliknya mengenakan kaos santai (t-shirt) dan terlebih lagi $t$-shirt dapat digunakan sebagai media cetak. Desain-desain pribadi dapat dituangkan ke atas kaos tersebut sehingga tidak terjadi kesamaan desain dengan baju yang dimiliki oleh orang lain.

Hal itulah yang menggerakkan pendiri Duo Langit untuk mendirikan Duo Langit. Awal terbentuknya Duo Langit tepat pada tahun 2014, ide tersebut muncul saat kedua pemilik yang sedang duduk di bangku perkuliahan mendapatkan pembelajaran tentang dunia bisnis yang mengharuskan kedua pemilik tersebut merancang dan meramu sebuah ide segar dalam berbisnis dan berusaha. Sebagai sebuah usaha jasa cetakan $t$-shirt, Duo Langit menggunakan sistem direct to garment (DTG). DTG merupakan proses printing obyek atau image ke media kain ( $t$-shirt) menggunakan printer yang dirancang khusus dan menggunakan tinta khusus tekstil yang membuat obyek yang dituangkan ke $t$-shirt tidak luntur untuk dicuci. Hasil printing akan menjadikan obyek yang dicetak meresap ke dalam bahan baju.
Untuk mendapatkan data yang memadai, penulis mewawancarai pemilik Duo Langit, yakni Seto dan Rizaq, sekaligus mengobservasi kiprah usaha mereka dalam mengembangkan nilai merek melalui pengamatan langsung dan pengumpulan dokumen-dokumen yang relevan. Selain itu, untuk memvalidasi data yang diperoleh, maka penulis juga melakukan wawancara triangulatif terhadap dua orang konsumen Duo Langit sekaligus mengobservasi sepak terjang mereka dalam mengkspresikan merek Duo langit melalui media sosial.

Dari data-data yang terkumpul, penulis kemudian menganalisis dengan melakukan seleksi, kategorisasi, validasi, teorisasi dan proposisi sebagaimana lazimnya teknik analisis data kualitatif(Wijaya, 2009 dalam Lestari, 2015). Seleksi dan kategorisasi dilakukan berdasarkan elemen-elemen dalam branderpreneurship sebagai panduan, sedangkan validasi dilakukan dengan menganalisis data-data dari informan triangulator. Adapun teorisasi dilakukan dengan menganalisis secara kesuluruhan, mengangkat temuan-temuan unik dan bermakna (insightful), lalu mendialogkannya dengan teori-teori dan konsep-konsep yang relevan untuk membangun argumen propositif. Dari hasil analisis ini dapat diketahui kekuatan dan kelemahan obyek dengan menggunakan kacamata circle of values development dari teori Wijaya tentang Branderpreneurship.

\section{Hasil Penelitian dan Pembahasan Analisis Branderpreneurship}

Wijaya (2011) menyebut ada beberapa faktor dapat dilihat dalam mengidentifikasi nilai merek, yaitu market insights, consumer insights dan brand insights. Dari segi market, dengan banyaknya jasa percetakan baju yang tersebar, masih sedikit yang menggunakan strategi branding dalam usaha mereka. Hal inilah yang membuat Duo Langit berani untuk menjadi salah satu jasa percetakan t-shirt dengan mengaplikasikan strategi branding di dalam usahanya. Bagi mereka, konsumen merupakan kunci dari berkembangnya usaha. 
Nilai merek yang terkandung dalam Duo Langit sangat menjunjung tinggi nilai identitas konsumen itu sendiri atau biasa disebut dengan nilai individualitas konsumen. Membicarakan konsumen, maka tipologi konsumen Duo Langit adalah anak muda baik wanita maupun pria dengan SES A dan B, usia berkisar antara 16 hingga 30 tahun.

Sementara itu, terciptanya nama merek Duo Langit memiliki arti yang begitu unik dan filosofis, yakni dua pemimpi. Nama Duo Langit juga berhubungan dengan tagline Duo Langit yang bermakna melangit sampai bumi, di mana nilai yang terkandung dari tagline tersebut adalah melangit itu diartikan seperti ide atau mimpi yang mengawang di atas awan dan bumi itu diartikan sebagai wadah dari implementasi ide-ide atau mimpi-mimpi tersebut sesuai jati diri konsumennya.

Adapun nilai fungsional Duo Langit adalah sebagai merek penyedia jasa kreasi fesyen ekspresif anak muda. Kualitas bahan, dapat dilihat dari material bajunya yang menggunakan kaos keluaran produk Gildan yang diimpor langsung dari Bangladesh. Jika dipakai, jenis kaos ini memiliki kenyamanan yang memberi rasa adem, tidak cepat molor, dan tidak cepat mengkerut. Jika ditinjau dari segi nilai emosional yang ditawarkan merek ke konsumen, Duo Langit menawarkan nilai lebih dari sisi individualitas, kebanggaan diri, dan nilai aktualisasi diri. Nilai simbolik yang ditawarkan ke konsumen adalah gaya hidup anak muda yang santai, bebas, suka berekspresi sebagai simbol anak muda yang kreatif. Nilai sosial dapat dilihat pada kepedulian Duo Langit terhadap hak konsumen untuk mengaktualisasikan diri, yang berdampak pada meningkatnya rasa percaya diri, membuat bangga akan diri sendiri dan merasakan kebebasan berekspresi. Untuk mendistribusikan dan mengantarkan nilai mereknya, Duo Langit menggunakan strategi online yaitu melalui media sosial Instagram dan offline melalui events.

Sementara itu, what-to-Say atau pesan yang ingin disampaikan Duo Langit ke konsumen bahwa Duo Langit merupakan salah satu cara untuk mendekatkan kegemaran atau hobi konsumen dalam mewujudkan cita-cita atau ide mereka melalui media cetak baju $t$-shirt. Sementara how-to-Say atau cara mengomunikasi nilai mereknya, Duo Langit membuat suatu program kampanye yaitu Show It. Show It adalah program kampanye Duo Langit yang bertujuan untuk mengajak orang-orang mau menunjukkan identitas diri mereka tanpa mereka merasa malu.

Where-to-Say atau media yang digunakan untuk mengomunikasikan nilai merek Duo Langit melalui program Show It adalah media sosial Instagram. Dipilihnya Instagram karena Instagram sendiri memiliki kelebihan dalam pengunggahan gambar. Di luar program tematik Show It, secara rutin dan reguler Duo Langit memang sering mengomunikasikan nilai merek mereka melalui media sosial, di samping melalui event, yang ditunjang dengan tools promo lainnya seperti Banner, Poster, Flyer, dan Pamflet. Adapun strategi when-toSay atau momen dan waktu yang tepat untuk mempromosikan program Show It adalah satu kali setiap minggunya. Jadi, ada empat kali promo program di setiap bulannya dan hal ini berlaku juga untuk bulan-bulan berikutnya dan seterusnya.

Terkait Customer Retention, Duo Langit memiliki strategi yang kreatif untuk membuat konsumennya melakukan pembelian ulang yaitu dengan cara membuat program Invasi. Invasi merupakan kegiatan direct ke konsumen, dalam bentuk kegiatan di mana Duo Langit mengirimkan desain baju yang telah mereka buat ke konsumen-konsumen tertentu. Desain baju yang mereka kirimkan tentunya sesuai dengan kegemaran masing-masing konsumen ataupun hal-hal yang disenangi oleh konsumen tersebut. Sementara untuk mengubah konsumen menjadi pelanggan, Duo Langit belum memiliki program customer loyalty khusus yang diberikan ke konsumen mereka. Demikian pula dalam membentuk brand community, Duo Langit masih belum memiliki program khusus yang dapat merangsang terciptanya komunitas merek Duo Langit sebagai merek jasa kreasi fesyen 
ekspresif anak muda.

Untuk self-audit, cara yang dilakukan Duo Langit untuk mengevaluasi nilai merek mereka adalah dengan melihat jumlah konsumen Duo Langit yang melakukan posting di Instagram mengenai kegemaran mereka. Sementara dalam competitive audit, meskipun Duo Langit sudah melakukan kegiatan branding, rupanya mereka masih belum paham dan mengerti siapa direct competitor mereka, bahkan mereka tidak terlalu mempedulikan adanya kompetitor. Salah satu alasan Duo Langit belum dapat menganalisis kompetitor mereka dengan baik dikarenakan kurang maksimalnya perhatian pemiliknya pada lingkungan usaha mengingat saat penelitian ini dilakukan, mereka masih berstatus mahasiswa tingkat akhir yang banyak disibukkan tugas akhir, sehingga perhatian merek pun terbelah.

Consumer audit atau evaluasi konsumen Duo Langit, dilakukan dengan melihat dari seberapa banyak konsumen yang menggunakan jasa mereka. Terlebih lagi kalau yang dicetak di kaos itu merupakan desain yang berasal dari konsumen sendiri dan bukan desain dari orang lain atau mengambil desain di sekitar mereka. Adapun trend audit tidak dilakukan oleh Duo Langit karena nature bisnisnya yang memang cenderung menghindari untuk mengikuti tren fashion yang sedang in. Hal ini dikarenakan Duo Langit justru selalu ingin mengajak orang-orang untuk tampil beda, mencoba untuk melawan arus alias tidak mainstream.

Terkait Updating values, Duo Langit berencana memperbarui atau menambahkan beberapa produk yaitu berupa tote bag dan bantal. Duo Langit juga berencana menambahkan jenis bahan printing baru seperti rubber dan plastisol. Sementara jika ditinjau dari target market, maka Duo Langit masih tetap ingin mempertahankan segmen anak muda, baik laki-laki maupun perempuan dengan SES A dan B.

Untuk komunikasi, Duo Langit berencana menambah media yang digunakan untuk mengomunikasikan sekaligus mendistribusikan nilai merek secara khusus ke konsumen berupa official webstore. Sementara dalam memperbarui bisnisnya, Duo Langit belum memiliki rencana pengembangan besar, karena masih merupakan merek baru di mana Duo Langit masih fokus pada pengenalan ke target market mereka.

Hasil penelitian secara keseluruhan mengenai strategi pengembangan nilai merek berdasarkan analisis branderpreneurship yaitu kewirausahaan berbasis branding yang dilakukan dan yang tidak dilakukan oleh Duo Langit dapat dilihat pada tabel 1 .

Tabel 1. Strategi Branderpreneurship Duo Langit

\begin{tabular}{|c|c|c|}
\hline Strategi & Asnek & Temuan Penelitian \\
\hline \multirow{3}{*}{ Identifying Value } & Market insight & $\begin{array}{l}\text { - Dengan banyaknya jasa percetakan baju yang } \\
\text { tersebar, masih sedikit yang menggunakan strategi } \\
\text { branding dalam usaha mereka. } \\
\text { - Duo Langit lebih menonjolkan nilai identitas dari } \\
\text { konsumen daripada nilai identitas Duo Langit. }\end{array}$ \\
\hline & Consumer insight & $\begin{array}{l}\text { - Duo Langit berusaha mengenali konsumen mereka } \\
\text { secara mendalam dari segi geografis, demografis, } \\
\text { lifestyle, dan psikografis } \\
\text { - Duo Langit mengidentifikasi konsumen mereka } \\
\text { berdasarkan NAIF yaitu Needs, Ambition, } \\
\text { Inspiration, dan Fear. }\end{array}$ \\
\hline & Brand insight & $\begin{array}{l}\text { Duo Langit mampu mengidentifikasi dan menganalisis } \\
\text { ornamen yang ada pada brand mereka yaitu logo, tagline, dan } \\
\text { nama merek untuk dijadikan brand positioning yang tepat } \\
\text { sebagai fondasi merek mereka. }\end{array}$ \\
\hline
\end{tabular}




\begin{tabular}{|c|c|c|}
\hline Strategi & Aspek & Temuan Penelitian \\
\hline \multirow{4}{*}{ Creating Values } & Functional & $\begin{array}{l}\text { Nilai yang ditawarkan masih basic dari segi fisik sebagai } \\
\text { fesyen anak muda yang menjadi medium kreativitas dengan } \\
\text { kelebihan pada kualitas hasil cetak desain. }\end{array}$ \\
\hline & Emotional & $\begin{array}{l}\text { Manfaat nilai yang ditawarkan Duo Langit dari segi emosional } \\
\text { adalah kebebasan, individualitas, dan aktualisasi diri. }\end{array}$ \\
\hline & Symbolic & $\begin{array}{l}\text { Manfaat nilai yang ditawarkan Duo Langit dari segi simbolik } \\
\text { adalah seperti gaya hidup anak muda yang santai, bebas, suka } \\
\text { berekspresi, sebagai simbol anak muda yang kreatif. }\end{array}$ \\
\hline & Social & $\begin{array}{l}\text { Manfaat nilai yang ditawarkan Duo Langit dari segi } \\
\text { sosial adalah kepedulian terhadap hak konsumen untuk } \\
\text { mengaktualisasikan diri sehingga menambah rasa percaya } \\
\text { diri, membuat bangga akan diri sendiri dan mengajak target } \\
\text { market untuk lebih berekspresi. }\end{array}$ \\
\hline \multirow[b]{2}{*}{$\begin{array}{l}\text { Delivering/ Distributing } \\
\text { Values }\end{array}$} & Online & $\begin{array}{l}\text { Duo Langit menjual nilai mereknya melalui media sosial } \\
\text { Instagram. }\end{array}$ \\
\hline & Offline & $\begin{array}{l}\text { Duo Langit menjual nilai mereknya melalui beberapa event } \\
\text { di Jabodetabek. Juga penjualan secara langusng ke personal } \\
\text { Duo Langit. }\end{array}$ \\
\hline \multirow{4}{*}{ Communicating Values } & What-to-say & $\begin{array}{l}\text { Duo Langit menyampaikan pesan nilai mereknya dengan } \\
\text { mengajak target market Duo Langit untuk tidak lagi merasa } \\
\text { malu menunjukkan identitas mereka ke publik melalui desain } \\
\text { yang dibuat oleh mereka. }\end{array}$ \\
\hline & How-to-say & $\begin{array}{l}\text { Duo Langit mampu mengembangkan kreativitas komunikasi } \\
\text { mereka melalui program Show It. }\end{array}$ \\
\hline & Where-to-say & $\begin{array}{l}\text { Program Show It dikomunikasikan melalui media sosial } \\
\text { Instagram dan beberapa event. }\end{array}$ \\
\hline & When-to-say & $\begin{array}{l}\text { Program Show It yang dikomunikasikan melalui media sosial } \\
\text { Instagram satu kali di setiap minggu pada setiap bulannya. }\end{array}$ \\
\hline \multirow{3}{*}{ Maintaining Values } & $\begin{array}{l}\text { Customer } \\
\text { Retention }\end{array}$ & $\begin{array}{l}\text { Duo Langit melakukan strategi Invasi untuk membuat } \\
\text { pelanggan mereka mau melakukan pembelian ulang. }\end{array}$ \\
\hline & Customer Loyalty & Tidak ada program khusus customer loyalty. \\
\hline & Brand Community & $\begin{array}{l}\text { Tidak ada program khusus yang dilakukan oleh Duo Langit } \\
\text { untuk membentuk brand community Duo Langit. }\end{array}$ \\
\hline
\end{tabular}




\begin{tabular}{|c|c|c|}
\hline Strategi & Aspek & Temuan Penelitian \\
\hline \multirow{4}{*}{ Evaluating Values } & Self Audit & $\begin{array}{l}\text { Cara yang dilakukan Duo Langit untuk mengevaluasi nilai } \\
\text { merek mereka adalah dengan melihat jumlah konsumen } \\
\text { Duo Langit yang melakukan posting di Instagram mengenai } \\
\text { kegemaran mereka. }\end{array}$ \\
\hline & Competitive Audit & $\begin{array}{l}\text { - Duo Langit masih belum mengevaluasi nilai merek } \\
\text { mereka terhadap direct competitor. } \\
\text { - Mereka belum mengetahui siapa yang menjadi direct } \\
\text { competitor mereka. } \\
\text { - Duo Langit hanya mengetahui dan melihat gerakan } \\
\text { dari beberapa indirect competitor mereka. }\end{array}$ \\
\hline & Consumer Audit & $\begin{array}{l}\text { Dalam mengevaluasi konsumen Duo Langit, mereka melihat } \\
\text { dari seberapa banyak konsumen yang menggunakan jasa } \\
\text { mereka dengan desain yang dibuat sendiri oleh konsumen } \\
\text { tersebut. }\end{array}$ \\
\hline & Trend Audit & $\begin{array}{l}\text { Mengenai tren dan gaya hidup saat ini, nilai merek Duo } \\
\text { Langit cenderung anti-mainstream (yang dapat dikonotasikan } \\
\text { sebagai 'anti-tren') }\end{array}$ \\
\hline \multirow{4}{*}{ Updating Values } & Product & $\begin{array}{l}\text { Duo Langit berencana menambahkan beberapa produk yaitu } \\
\text { tote bag, bantal, dan jenis bahan printing baru seperti rubber } \\
\text { dan plastisol. }\end{array}$ \\
\hline & Market & $\begin{array}{l}\text { Duo Langit belum berencana untuk menambah atau } \\
\text { memperluas target market mereka. }\end{array}$ \\
\hline & Communication & $\begin{array}{l}\text { Duo Langit sedang mengembangkan webstore khusus yang } \\
\text { ditujukan ke target market mereka. }\end{array}$ \\
\hline & Business & Masih belum ada pengembangan bisnis maupun franchise. \\
\hline
\end{tabular}

(Sumber: Hasil analisis)

\section{Membangun Merek dengan Kustomisasi dan Personalisasi}

Menciptakan nilai merek dalam suatu usaha diperlukan kejelian terhadap keunikan sendiri yang sekiranya dapat ditawarkan ke konsumen. Hal ini sangat disadari oleh Duo Langit, di mana Duo Langit berusaha menciptakan nilai merek yang menggabungkan kebutuhan dan keinginan konsumen. Kebutuhan akan baju t-shirt yang bisa didesain oleh konsumen serta keinginan menunjukkan identitas konsumen. Sehingga, nilai merek yang terkandung dalam Duo Langit merupakan gabungan antara customizing dan personalizing produk sesuai target market mereka. Customize adalah di mana para konsumen dapat dengan bebas menyalurkan ide-ide mereka melalui desain yang mereka buat dan dituangkan ke media baju $t$-shirt.

Bersama Duo Langit, konsumen bebas mengekspresikan ide mereka sesuka hati mereka, membuat desain baju yang sesuai dengan keinginan mereka. Dengan demikian, Duo Langit mendorong konsumen untuk lebih berekspresi melalui media kaos. Selain nilai kustomisasi, (customized product), terdapat pula nilai personalisasi (personalized product) 
yaitu desain baju yang diekspresikan oleh para konsumen Duo Langit merupakan bukti dari identitas mereka. Desain yang dibuat oleh konsumen merupakan bentuk dari ide-ide konsumen yang bertujuan untuk menunjukkan siapa diri mereka secara personal ke publik.

Menurut Russell dalam Santoso (2013), generasi konsumen yang berpengaruh dengan memiliki rasa individualisme yang kuat dapat mengarahkan mereka untuk mencari produk kustomisasi dan personalisasi. Selain itu, keterlibatan pelanggan tampaknya menjadi salah satu yang mendasar, yang merupakan cara baru penciptaan dan pengembangan nilai, di mana konsumen dilibatkan secara aktif dalam proses penciptaan nilai sehingga nilai tambah dapat bersama-sama disesuaikan secara pas (De Chernatony dan McDonald dalam Santoso, 2013).

Dalam kasus ini produsen dan konsumen bekerjasama dalam menghasilkan produk akhir, sehingga memberi nilai tambah bagi produk. Menurut Santoso (2013), konsumen tidak berperan sebagai pengguna pasif suatu produk/ layanan, tetapi juga aktif dalam proses pengembangan, sehingga pembeli dapat mengkonstruk identitas diri melalui produk yang melibatkan mereka.

Telah banyak jasa percetakan baju yang menawarkan jasa yang sama dengan Duo Langit. Meski demikian belum tentu nilai yang ditawarkan oleh mereka memiliki kesamaan dengan Duo Langit. Ada yang menawarkan nilai customized namun belum tentu menawarkan nilai personalized, dan ada pula yang menawarkan nilai personalized namun belum tentu menawarkan nilai customized. Duo Langit menggabungkan kedua nilai tersebut. Dengan demikian, bukan saja kebebasan dalam membuat desain yang konsumen dapatkan namun juga peluang untuk dapat menunjukkan identitas mereka secara personal melalui desain yang mereka custom.

Dalam konteks ini, dapat dikatakan bahwa Duo Langit merupakan UKM yang sangat memperhatikan keselarasan nilai mereknya dan nilai-nilai individu konsumennya, yakni anak muda. Anak muda yang memiliki kebutuhan akan suatu media yang dapat menyalurkan ide-ide ataupun mimpi mereka, dan dapat meninggalkan tanda jejak identitas mereka melalui media tersebut. Di sinilah peran Duo Langit sebagai media yang dapat mewujudkan ekspresi dan komunikasi identitas diri anak muda melalui fesyen yang customized dan personalized.

\section{Membangun Merek dengan Menciptakan Kebanggaan Diri Konsumen}

Maslow dalam Mendari (2010) mengatakan terdapat lima hierarki kebutuhan yaitu: Physiological needs, Safety needs, Belongingness and Love needs, Esteem needs, dan Self-Actualization needs. Physiological needs merupakan real needs yang secara fisiologis dapat dikatakan sebagai kebutuhan pokok manusia. Safety needs terkait kebutuhan akan keamanan, baik fisik maupun psikologis seperti kebutuhan untuk diperlakukan adil dan manusiawi. Belongingness and Love needs terkait kebutuhan akan kasih sayang dan rasa memiliki. Esteem needs terkait kebutuhan akan harga diri, termasuk reputasi, prestise, dan pengakuan dari orang lain. Terakhir, Self-Actualization needs terkait kebutuhan untuk pemenuhan diri menjadi yang terbaik dari kemampuan, keterampilan dan potensi yang dimiliki.

Berdasarkan hirarki dari Maslow tersebut, maka dapat dikatakan bahwa Duo Langit berusaha memenuhi kebutuhan aktualisasi diri dari konsumen sekaligus memberikan kebanggaan yang dapat meningkatkan harga diri dan prestise konsumen melalui nilai customized dan personalized product yang memfasilitasi ide asli konsumen. Hasil cetak desain yang sesuai dengan keinginan konsumen dapat pula menjadi medium konstruksi identitas diri konsumen Duo Langit. Bukan itu saja, dengan memenuhi kebutuhan aktualisasi diri konsumen ternyata memberi nilai tambah lebih bagi kehidupan personal dan sosial konsumen.

Pengaruh dalam hidup $g w$ ya paling $g w$ nyaman sih pakai 
kaos itu dan gw juga lebih pede sih karena beda dan $g w$ pribadi lebih suka kaos yang polos dengan tulisan yang $g w$ mau kayak tulisan aneh yang kadang orang mikir harus dua kali baru ngeh kalau itu tulisan apa dan ya $g w$ bangga, ini desain bikinan $g w$ sendiri (Wawancara dengan Richard pada tanggal 11 Maret 2015).

Dari pernyataan salah satu konsumen Duo Langit di atas, dapat dilihat bahwa Duo Langit mampu membawa pengaruh yang positif di dalam kehidupan konsumennya. Pengaruh positif tersebut adalah menumbuhkan rasa percaya diri dan kebanggaan atas diri mereka sendiri. Mereka bisa merasakan kebanggaan diri melalui kreasi desain yang mereka buat sendiri yang berasal dari ide-ide atau mimpi-mimpi mereka.

Kebanggaan diri yang dirasakan oleh konsumen biasanya terlihat dari keaktifan mereka dalam mengunggah foto mereka ketika menggunakan kaos yang dicetak oleh Duo

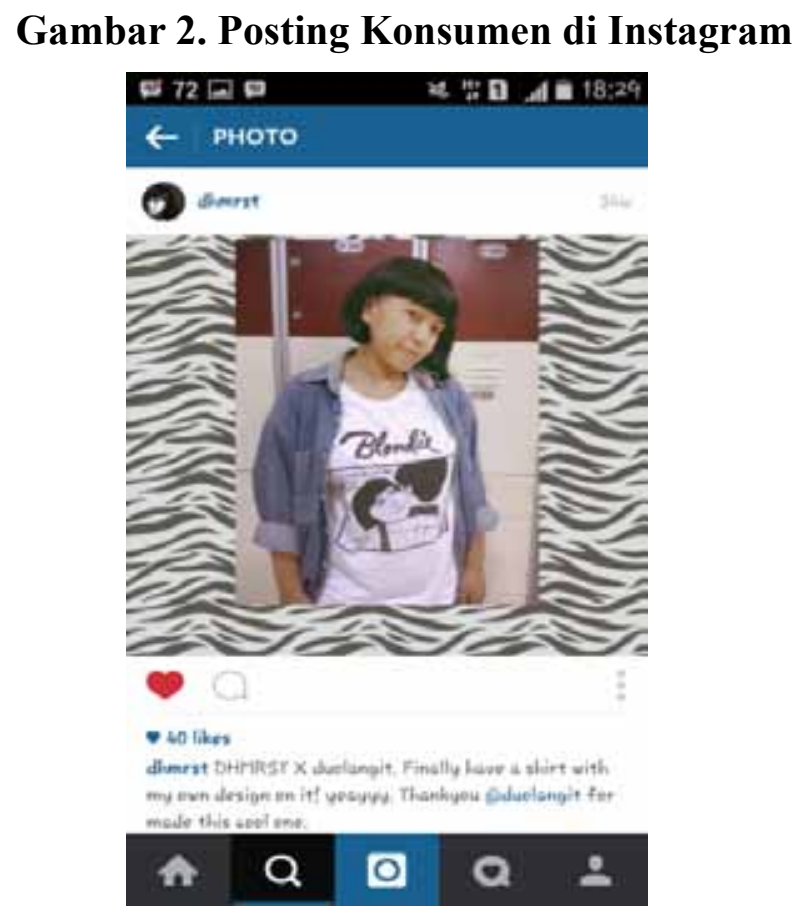

sumber: Instagram Duo Langit
Langit dengan desain yang mereka buat. Mereka mengunggah foto mereka melalui media sosial Instagram atupun media sosial lainnya. Salah satu contoh posting yang dibuat oleh konsumen Duo Langit dapat dilihat pada gambar 2.

Dengan upaya membuat kebanggaan diri konsumen tersebut, Duo Langit mencoba mengerti dan memahami keinginan konsumennya. Desain serumit apapun, Duo Langit selalu berusaha mewujudkan secara nyata sesuai harapan konsumen. Sehingga, melalui desain yang dibuat oleh konsumen dan dengan hasil cetakan yang maksimal dapat memberi kepuasan dalam menampilkan identitas diri sebagaimana yang dirasakan oleh konsumen Duo Langit.

Bukan kebanggaan diri saja yang dapat dirasakan oleh konsumen, namun nilai Duo Langit juga mendorong konsumen untuk terus berkreasi dan berkarya melalui desain yang mereka buat pada medium $t$-shirt yang disediakan oleh Duo Langit. Hal ini membuat Duo Langit menjadi sebuah merek yang memiliki tanggung jawab sosial dalam memprovokasi secara positif pertumbuhan kreativitas anak muda. Seperti pernyataan informan triangulator Intan yang merupakan salah satu konsumen Duo Langit:

Jadi, karena udah nyetak di Duo Langit jadi mempengaruhi $g w$ untuk lebih pengen lagi berkarya, berekspresi dan mengaplikasikannya ke dalam sebuah baju ataupun media-media yang lain gitu (Wawancara dengan Intan pada tanggal 10 Maret 2015).

\section{Membangun Merek dengan Strategi Komunikasi yang Terkonsep}

Komunikasi sangat dibutuhkan untuk membantu suksesnya suatu kegiatan branding dalam usaha. Sebagaimana dikatakan Wijaya (2013), "branding is the process of creation or legacy of certain trail signs in the minds and hearts of consumers through a variety of communication ways and strategies so that create specific 
meaning and feeling which affect consumers' lives" (hal. 55). Jadi pemerekan atau branding adalah proses penciptaan atau peninggalan tanda jejak di kepala dan hati konsumen melalui berbagai cara komunikasi sehingga menciptakan makna dan perasaan tertentu yang berdampak bagi kehidupan konsumen. Sama halnya yang dilakukan oleh Duo Langit, di mana mereka mampu menciptakan komunikasi terarah kepada konsumen. Maksud dari komunikasi terarah adalah melakukan perencanaan strategis dalam mencapai tujuan pemerekan Duo Langit.

Menurut Abraham (2006), "strategic planning is the process by which one develops a strategy to achieve certain purposes" (hal. 9). Perencanaan strategis adalah proses mengembangkan sebuah strategi untuk mencapai keinginan atau tujuan tertentu. Demikian pula dengan Duo Langit, yang dalam mencapai tujuan mereka melakukan komunikasi secara lebih terkonsep, yakni komunikasi terarah melalui suatu perencanaan yang strategis.

Salah satu upaya yang dilakukan Duo Langit dalam mengomunikasikan nilai mereknya adalah melalui program kampanye Show It di Instagram. Program kampanye ini memiliki pesan yang jelas terkait dengan nilai merek Duo Langit. Show It ('Tunjukkan!') berarti mendorong konsumen untuk bangga menunjukkan hasil karyanya melalui fesyen ekspresif yang difasilitasi oleh Duo Langit. Hal ini sesuai dengan brand positioning Duo Langit sebagai merek fesyen ekspresif anak muda yang menjadi medium kreativitas konsumen dalam menuangkan ide-ide orisinal mereka. Duo Langit melakukan perencanaan terarah yang bagus, kuat, dan unik dalam mengomunikasikan nilai mereknya melalui program Show It ini ke target market. Mereka menyusun strategi dengan menentukan pesan, media, dan timing strategy program kampanye Show It tersebut.

Banyak merek usaha baru yang belum atau bahkan tidak melakukan komunikasi terkonsep, salah satu contohnya adalah Waxing Corner (Wijaya \& Hanathasia, 2012). Waxing Corner merupakan salah satu UKM yang bergerak di bidang usaha perawatan kecantikan, yakni waxing dan spa untuk wanita. Sebagai merek usaha baru, Waxing Corner tidak melakukan perencanaan komunikasi yang terarah. Hal tersebut disebabkan karena keterbatasan pengetahuan mengenai branding. Di mana tidak ada pengembangan kreativitas komunikasinya ke konsumen. Waxing Corner hanya menawarkan keunggulan produk secara langsung sesuai apa yang ingin disampaikan (Wijaya \& Hanathasia, 2012).

Duo Langit adalah salah satu dari sedikit merek UKM yang melakukan branding melalui kegiatan komunikasi yang terarah sesuai dengan segmen khalayak konsumennya. Dengan program yang dibuat oleh Duo Langit secara strategis tersebut, membuktikan bahwa Duo Langit berusaha menyampaikan nilai mereknya secara serius dengan cara yang berbeda. Dari penelusuran penulis, tidak semua merek dalam kategori sama mampu melakukan kegiatan komunikasi terarah seperti yang dilakukan oleh Duo Langit.

\section{Membangun Merek dengan Pendekatan yang Kreatif}

Suatu merek harus mampu melakukan pendekatan kepada target market mereka, di mana pendekatan yang dilakukan merupakan bentuk dari strategi yang dimiliki oleh sebuah merek di pasar. Menurut Drewniany \& Jewler (2011), "Creative ads make a relevant connection between the brand and its target audience and present a selling idea in an unexpected way" (hal. 2). Konsumen ingin tahu siapa kita (merek), kebiasaan kita (merek), dan nilai yang kita (merek) miliki. Konsumen menginginkan kepercayaan pada suatu merek. Jika mereka terhubung dengan suatu merek melalui beberapa keperluan dasar mereka, dan mereka percaya bahwa sesuatu tersebut ada pada suatu merek, maka mereka akan dengan senang hati membeli dan menggunakan produk yang merek tawarkan.

Sebuah merek harus mampu melakukan pendekatan dengan menjual ide yang bersifat rasional, emosional, atau gabungan dari 
keduanya. Kompetitor dapat saja meniru produk dan layanan yang ditawarkan, maka menjual ide dari segi emosional akan lebih baik dan kuat daripada hanya dari segi rasionalnya saja. Dengan demikian, untuk melakukan pendekatan yang kreatif diperlukan cara yang tidak terduga tapi tetap relevan (unexpected but relevant) terhadap target market (Drewniany \& Jewler, 2011).

Di sini, Duo Langit membuat sebuah strategi yang unik dan berbeda daripada merek UKM lain pada umumnya, yaitu melakukan pendekatan melalui Invasi. Pendekatan ini dilakukan untuk membuat para pelanggan Duo Langit bersedia melakukan pembelian ulang pada produk dan layanan yang ditawarkan Duo Langit. Pendekatan yang dilakukan oleh Duo Langit merupakan cara yang tidak dapat diduga oleh para konsumen mereka dan pendekatan tersebut masih relevan dengan nilai merek Duo Langit serta sesuai dengan konsumen Duo Langit. Invasi yang dilakukan Duo Langit dengan mengintrusi gairah konsumen untuk selalu memikirkan ide-ide desain baru mereka merupakan langkah strategis yang dapat mendorong konsumen melakukan repeat order.

Kata kunci kita memang kreatif dan strategi, karena itu memang core business kita. Tapi kita ingin kreatif ini menjadi culture, makanya kita mengusung konsep medium kreativitas yang melibatkan konsumen. Jadi, kayak memasyarakatkan kreatif dan mengkreatifkan masyarakat, he he... (Wawancara dengan Seto pada tanggal 16 Februari 2015).

Kluyver dalam Abraham (2006) menjelaskan bahwa "strategic thinking focuses on taking different approaches to delivering customer value [and] on thereby provide a basis for sustainable competitive advantages" (hal. 175). Pendekatan yang kreatif juga memerlukan pemikiran yang strategis, yaitu fokus membuat sebuah strategi yang berbeda untuk menyampaikan nilai merek ke konsumen. Dengan demikian, komunikasi yang kreatif dan strategi relasi yang strategis menjadikan Duo Langit sebagai merek yang berbeda dari pesaingnya. Hal ini dapat membawa dampat positif bagi keberlangsungan suatu usaha.

\section{Membangun Merek dengan Visi dan Inovasi}

Dalam mengembangkan nilai merek, Duo Langit merupakan merek yang memiliki visi untuk mengembangkan fitur-fitur di produk yang mereka sediakan. Dengan pembaruan ataupun tambahan fitur dan varian dapat meningkatkan nilai merek Duo Langit. Duo Langit memiliki pikiran untuk berani berinovasi dan tidak berhenti di satu titik produk atau layanan yang mereka tawarkan bagi konsumen.

Kreativitas itu nggak boleh

berhenti. Kalo kreativitas berhenti, matilah Duo Langit, karena creativity is Duo Langit dan Duo Langit is creativity. Masih banyak ide yang akan kita kembangkan ke depan, yang pasti kita ingin membuat semakin banyak anak muda yang bahagia dan bangga dengan diri mereka, yaaah.. semakin pedelah, semakin berani nunjukin ide sendiri... (Wawancara dengan Rizaq pada tanggal 9 Februari 2015).

Fontana (2009: 20-22) menjelaskan bahwa inovasi tidak saja berarti "kebaruan" atau sesuatu yang baru, barang dan/ atau jasa baru atau sistem produksi baru atau cara memasarkan yang baru; "kebaruan" itu harus menciptakan nilai guna bagi konsumen dan nilai tambah bagi produsen; "kebaruan" yang menghasilkan kesuksesan ekonomi dan sosial, pada konteks inovasi dan penciptaan nilai tingkat individu, organisasi, dan masyarakat.

Pembaruan dalam inovasi dilihat sebagai perubahan besar atau drastis yang merupakan hasil kombinasi sumber daya yang sudah ada 
atau hasil kombinasi sumber daya baru dalam perusahaan. Perubahan tersebut terjadi karena ada pemahaman yang baik atas situasi dan kondisi pasar, kebutuhan dan tuntutan pembeli (consumers) atau pengguna (users) produk yang semakin meningkat, seperti tuntutan kualitas produk yang lebih baik, tersedianya layanan purnajual yang paripurna, dan harga yang wajar (lebih rendah daripada nilai manfaat produk yang ditawarkan) (Fontana: 2009).

Duo Langit mengembangkan strategi pengkinian nilai merek melalui beberapa tambahan pada fitur dan varian produk ataupun komunikasi mereka. Varian yang ditambahkan ke produk mereka adalah berupa tote bag, bantal, bahan printing sejenis rubber dan plastisol. Sedangkan untuk pengembangan fitur komunikasi, Duo Langit menjajal sebuah webstore yang berkontenkan informasi detil dan komprehensif mengenai merek, juga memudahkan akses bagi konsumen untuk menggunakan layanan dan produk Duo Langit. Dengan pembaruan dan penambahan berbagai fitur, Duo Langit menjadi salah satu merek yang memiliki pandangan ke depan terkait pengembangan nilai merek dan usaha mereka.

Dalam pengembangan produk, penyempurnaan dan perbaikan dapat dilakukan atas produk yang dihasilkan meliputi bidang mutu, corak, penampilan, dan lain sebagainya. Pada umumnya kegiatan pengembangan produk mempunyai hubungan erat dengan kegiatan inovasi, sehingga unsur-unsur teknologi memegang peranan yang cukup menentukan dalam kegiatan pengembangan produk (Assauri: 2010). Tak heran, teknologi menjadi salah satu unsur yang menjadi perhatian Duo Langit, baik teknologi komunikasi (media) maupun teknologi produk dan layanan. Dalam hal ini, Duo Langit berusaha menjadi 'sahabat teknologi' bahkan menjadikan teknologi sebagai pilar penting pengembangan nilai dan komunikasi merek.

Secara ringkas, strategi Duo Langit dalam mengembangkan nilai merek dari kacamata Branderpreneurship dapat dipetakan seperti pada gambar Lampiran 1. Ada beberapa elemen strategi yang dilakukan dan tidak dilakukan oleh Duo Langit dalam pengembangan nilai merek. Pada tahap Identifying values misalnya, Duo Langit mampu mengidentifikasi market insight, consumer insight, dan brand insight mereka dengan baik. Dengan melakukan identifikasi nilai merek, maka dapat menjadi pondasi kuat bagi Duo Langit dalam menegaskan brand postioning di benak khalayak konsumen.

Pada tahap Creating values, Duo Langit menawarkan manfaat nilai merek dari segi fungsional terkait jaminan kualitas produk mereka. Dari segi emosional, simbolik, dan sosial Duo Langit mampu menawarkan manfaat ke konsumen mereka secara unik dan personal. Duo Langit mendistribusikan nilai mereknya melalui media sosial Instagram dan berbagai event yang ada di sekitar daerah Jabodetabek.

Duo Langit mampu mengembangkan strategi dalam mengomunikasikan nilai mereknya, yaitu dengan mengembangkan pesan apa yang ingin mereka sampaikan ke konsumen sesuai nilai merek. Melalui program Show It di Instagram dan timing plan yang tepat, maka Duo Langit mampu melakukan komunikasi yang terarah ke konsumen mereka. Duo Langit juga dapat melakukan pendekatan yang kreatif melalui program Invasi ke konsumen, di mana cara yang dilakukan Duo Langit ini berbeda dengan kompetitor mereka.

Namun demikian, Duo Langit masih belum dapat membentuk program loyalti dan komunitas merek dikarenakan sebagai merek UKM baru, Duo Langit masih dalam tahap perkenalan ke target market mereka. Padahal, Duo Langit sebenarnya tak perlu menunggu lama untuk membuat program loyalti dan membentuk komunitas pecinta merek dengan tujuan untuk mengubah konsumen menjadi pelanggan yang loyal dan dapat mencintai nilai merek yang ditawarkan.

Duo Langit sudah mampu mengevaluasi nilai mereknya berdasarkan kondisi konsumen mereka, apa yang menjadi keinginan dan kebutuhan konsumen, serta tren dan gaya hidup saat terkini. Namun Duo Langit masih belum 
mampu mengevaluasi direct competitor mereka. Padahal competitive analysis sangat diperlukan untuk melihat perkembangan nilai merek di antara para pesaing di pasaran. Terakhir, dalam hal memperbarui nilai merek, Duo Langit hanya mampu memiliki perencanaan yang inovatif terkait produk dan komunikasinya saja, namun tidak dari segi pasar dan bisnis yang menunjukkan kelemahan Duo Langit dalam macro strategy.

\section{Simpulan}

Meskipun tergolong usaha kecil dan relatif baru, namun Duo Langit memberikan angin segar dengan ide-ide dan aksinya yang inovatif dan kreatif. Di antaranya adalah dengan menawarkan produk inovatif melalui jasa kreatif personalisasi dan kustomisasi desain t-shirt. Di sini Duo Langit dapat dikatakan memahami insights konsumen anak muda yang menjadi sasarannya, yakni rasa bangga pada diri sendiri yang kemudian memunculkan keinginan untuk melakukan aktualisasi diri dengan mewujudkan dan mengekspresikan ideide sendiri. Jika selama ini apa yang dikenakan anak muda adalah hasil kreasi orang lain yang kemudian diapresiasi dengan membeli karya tersebut dan mengenakannya, maka Duo Langit memediasi keinginan terpendam anak muda yang ingin menunjukkan ide-ide orisinalnya, mengekspresikannya dan (bahkan) mengomunikasikannya kepada lingkungan sekitarnya melalui medium fesyen atau $t$-shirt beserta asesorisnya.

Dengan demikian, anak muda menjadi bebas memenuhi kebutuhan aktualisasi dirinya melalui Duo Langit. Dalam konteks ini, Duo Langit tidak sekadar menawarkan nilai fungsional merek usahanya sebagai penyedia jasa kreasi fesyen ekspresif anak muda, tetapi juga nilai emosional dengan memberikan kebanggaan diri konsumen anak muda. Tak hanya itu, Duo Langit juga memberikan nilai simbolik mereknya sebagai simbol gaya hidup kreatif dan ekspresif anak muda. Bahkan, secara sosial, Duo Langit menunjukkan rasa pedulinya dalam menciptakan komunitas konsumen anak- anak muda kreatif yang bebas dan percaya diri dalam mengekspresikan idenya, serta menyediakan wadah dalam mengaktualisasikan diri sehingga dengan kebebasan itu anak muda menjadi lebih bahagia dan semakin mengenal diri mereka sendiri.

Tak berhenti pada kejelian membaca insights anak muda dalam menawarkan produk, Duo Langit juga secara kreatif menciptakan cara-cara komunikasi dan distribusi nilai yang cenderung berbeda dari pesaingnya. Selain melalui media sosial, Duo Langit mendistribusikan nilainya melalui event-event menarik. Dalam berkomunikasi, Duo Langit merencanakan secara strategis dan terarah sehingga dapat menyampaikan pesan-pesan mereknya secara cerdik, unik, efisien dan efektif. Dengan visi dan perencanaan yang jelas, maka Duo Langit berpotensi untuk berkembang menjadi merek yang kuat di kategorinya. Duo Langit hanya perlu menguatkan strategi evaluasi nilainya yang tampaknya masih lemah, agar dapat terus berinovasi dan tidak kalah dalam kancah persaingan yang semakin cepat dan ketat. Dengan demikian, pengkinian (updating) dan peningkatan (upgrading) nilai mereknya pun dapat terus dilakukan secara relevan dan kontinyu seiring berkembangnya bisnis usahanya.

\section{Daftar Pustaka}

Abraham, S. C. (2006). Strategic Planning a Practical Guide for Competitive Success. Ohio: South-Western. Assauri, S. (2010). Manajemen Pemasaran; Dasar, Konsep, dan Strategi. Jakarta: Rajawali Pers. Drewniany, B. L \& Jewler, A. J. (2011). Creative Strategy in Advertising. Ed. 10. USA: Wadsworth. Fontana, A. (2009). Innovate We Can! How to Create Value through Innovation in Your Organization and Society. Jakarta: Grasindo Keller,K.L.(2013).Strategic BrandManagement. New Jersey: Pearson Education. Lestari, C. S. (2015). Gaya dan Perilaku Account 
Executive Agensi Periklanan Saat Deadline: Studi Etnografi Komunikasi. Jurnal Universitas Bakrie, Vol. 3 No. 3. Mendari, A. S. (2010). Aplikasi Teori Hierarki Kebutuhan Maslow dalam Meningkatkan Motivasi Belajar Mahasiswa. Jurnal STIE Musi Palembang Rachman, S. (2016). Analisis Pengaruh Perkembangan Usaha Kecil dan Menengah Sektor Manufaktur Terhadap Pertumbuhan Ekonomi di Kota Makassar. Jurnal Ad'ministrare, Vol. 3 No. 2, hal. 71-82 Sadat, A. M. (2009). Brand Belief; Strategi Membangun Merek Berbasis Keyakinan. Jakarta: Salemba Empat Santoso, O. C. (2013). Personalized Marketing Sebagai Upaya Menciptakan Keunggulan Bersaing Perusahaan. Jurnal Jurusan Manajemen Fakultas Bisnis Universitas Katolik Widya Mandala Surabaya Suharyanti (2011). Memenangkan Pasar dengan Strategi Brand Extension. Jakarta: UB Press.

Wijaya, B. S. (2011). Branderpreneurship: Brand Development-Based Entrepreneurship. Proceeding International Conference on Business and Communication (ICBC).

Wijaya, B. S. \& M. Hanathasia (2012). Analisis Branderpreneurship Pada
UKM Perawatan Kecantikan: Kasus Salon "Waxing Corner". Prosiding Seminar Nasional Kewirausahaan dan Inovasi Bisnis II, Jakarta Wijaya, B. S. (2012). The Development of HierarchyofEffectsModelinAdvertising. International Research Journal of Business Studies, Vol. 5, No. 1, hal. 73-85

Wijaya, B. S. (2013). Dimensions of Brand Image: A Conceptual Review from the Perspective of Brand Communication. European Journal of Business and Management, Vol. 5, No. 31, hal. 55-65

Wijaya, B. S. \& A.H. Sutawidjaya (2015). Planted with Word-of-Mouth, Flourished with Social Media Communications: How a Small Business Brand in Indonesia Grows Globally in the 'Land' of Branderpreneurship. International JournalofAppliedBusinessandEconomic Research, Vol. 13, No. 5, hal. 3393-3408

Wijaya, B. S., Suharyanti, M. Hanathasia \& D. Kania (2016). Synergizing Entrepreneurial Spirit and the Mindset of Branding through Branderpreneurship: Evidences from Indonesia. Social Sciences, Vol. 11, No. 2, hal. 129-138 www.bps.go.id www.depkop.go.id www.instagram.com/duolangit 